\title{
Evaluation of Postharvest Removal of Sooty Blotch and Flyspeck on Apples Using Sodium Hypochlorite, Hydrogen Peroxide with Peroxyacetic Acid, and Soap
}

\author{
J. C. Batzer, M. L. Gleason, and B. Weldon, Department of Plant Pathology, P. M. Dixon, Department of Statis- \\ tics, and F. W. Nutter, Jr., Department of Plant Pathology, Iowa State University, Ames 50011
}

\begin{abstract}
Batzer, J. C., Gleason, M. L., Weldon, B., Dixon, P. M., and Nutter, F. W., Jr. 2002. Evaluation of postharvest removal of sooty blotch and flyspeck on apples using sodium hypochlorite, hydrogen peroxide with peroxyacetic acid, and soap. Plant Dis. 86:1325-1332.

Postharvest dips of apples (Malus $\times$ domestica) in commercial disinfestants were used to remove signs of the flyspeck (FS) pathogen, Schizothyrium pomi, and the sooty blotch (SB) complex (Peltaster fructicola, Leptodontium elatius, and Geastrumia polystigmatis). Apples were dipped for 7 or $15 \mathrm{~min}$ in buffered sodium hypochlorite (Agclor 310 plus Decco 312 Buffer) at $200,400,500,600$, or $800 \mathrm{ppm}$ chlorine, a mixture of hydrogen peroxide and peroxyacetic acid (Tsunami 100) at $60 \mathrm{ppm} / 80 \mathrm{ppm}, 120 \mathrm{ppm} / 160 \mathrm{ppm}$, or $360 \mathrm{ppm} / 480 \mathrm{ppm}$, respectively, or soap (Kleen 440), then brushed and rinsed for $30 \mathrm{~s}$ on a commercial grading line. Disease severity was assessed as percent diseased area using a quantitative rating system, and by counting the number of colonies of three mycelial types of SB and FS. Percent diseased area on apples was converted to USDA apple grade ratings and retail values. Both assessment methods provided similar results, but the percent-diseased-area method was less labor intensive. A 7-min dip in $800 \mathrm{ppm}$ chlorine resulted in a mean increase from 25 and 55\% to 100\% Extra Fancy grade for 'Jonathan' and 'Golden Delicious' apples, respectively, and increased market value by 31 and $14 \%$, respectively. The 7-min, 200-ppm chlorine dip resulted in an increase from 28 and $45 \%$ to 92.5 and $96.5 \%$ Extra Fancy after treatment for 'Jonathan' and 'Golden Delicious', respectively. Blemishes were removed more effectively from 'Jonathan' and 'McIntosh' apples than from 'Golden Delicious'. Mycelial types of the sooty blotch and flyspeck fungi were removed differentially by the disinfestant dip treatments.
\end{abstract}

Additional keywords: disease assessment, epidemiology

Flyspeck (FS), caused by Schizothyrium pomi (Mont. \& Fr.) Arx. (anamorph: Zygophiala jamaicensis E. Mason), and the sooty blotch (SB) complex, caused by at least three different fungal species (Peltaster fructicola Johnson, Sutton \& Hodges, Leptodontium elatius (G. Mangenot) De Hoog, and Geastrumia polystigmatis Batista \& M.L. Farr (29)), are major diseases of commercial apples (Malus $\times$ domestica Borkh.) in eastern North America and worldwide. The SB and FS fungi grow on the epicuticular wax layer of apples $(15,18,23)$. No cultivar resistance has been reported. Several different SB and FS fungi often coexist in the same orchards and on the same fruit $(13,29)$. Sooty blotch appears as a dark smudge-like blemish on the apple surface, whereas FS resembles fecal spots left by

Corresponding author: M. L. Gleason

E-mail: mgleason@iastate.edu

Journal Paper no. J-19411 of the Iowa Agriculture and Home Economics Experiment Station, Ames. Project no. 3564, supported by Hatch Act and State of Iowa Funds.

Accepted for publication 10 July 2002.

Publication no. D-2002-1007-01R

(C) 2002 The American Phytopathological Society differential efficacy of fungicides against certain fungi within the SB complex has been shown. For example, benomyl is less effective against $P$. fructicola than $L$. elatius (12), whereas captan is less effective against $L$. elatius than $P$. fructicola $(2,4)$. Effective postharvest removal of SB and FS on apples could allow growers to compensate for inadequate control of these diseases in the orchard and to potentially reduce the number of fungicide sprays.

Sodium hypochlorite dips can reduce populations of Escherichia coli strain O157:H7, Botrytis cinerea, Mucor piriformis, and Penicillium expansum on fruits and vegetables $(3,16,26,29)$ and reduce severity of SB and FS $(6,10,30)$. In 1920, Colby reported the effectiveness of "Javelle water" (chlorinated water) in removing SB (6). Hendrix demonstrated that a 5- to 7-min dip in $500 \mathrm{ppm}$ chlorine, followed by brushing and a fresh water rinse, reduced incidence of SB from 100 to $0 \%$ and FS from 100 to $27 \%$ (10). In laboratory trials, the most effective method to eliminate E. coli strain O157:H7 from whole apples was a 15-min dip in a solution of hydrogen peroxide and peroxyacetic acid $(11,25,30)$. Since these materials have demonstrated value as disinfestants in apple cider processing, their potential value in eradication of SB and FS signs on freshmarket apples also merits investigation.

In order to adequately quantify the benefits of various dips, reliable and costefficient assessment methods are needed. In this study, two different methods were used to assess the effectiveness of concentration and dip time in sodium hypochlorite solutions, and in mixtures of hydrogen peroxide and peroxyacetic acid, on removal of SB and FS from 'Jonathan' and 'Golden Delicious' apples. The influence of disinfestant dips on the removal of various SB and FS mycelial types was also evaluated. A preliminary report has been published (1). A preliminary experiment using sodium hypochlorite and soap to remove SB and FS from 'McIntosh' and 'Golden Delicious' apples is also presented.

\section{MATERIALS AND METHODS}

Experiment 1. 'McIntosh' apples were harvested from the Iowa State University Horticulture Station near Gilbert, IA, on 10 September 1998, and 'Golden Delicious' apples were harvested from a commercial orchard near Indianola, IA, on 18 September 1998. 'McIntosh' apples were very 
lightly blemished $(<3 \%$ of the apple surface). 'Golden Delicious' apples were severely blemished on only one side of the apple due to a fungicide application failure. Fruit were arbitrarily sorted into seven crates of 50 apples and stored at $1{ }^{\circ} \mathrm{C}$ for 2 weeks until treatment.

SB and FS were rated separately on each apple. 'McIntosh' apples were rated according to total number of $\mathrm{SB}$ and FS colonies on the apple. On 'Golden Delicious' apples, percent coverage on the hemisphere with severe SB and FS infections was rated as follows: $0=$ none; $1=$ 0.1 to $4 \% ; 2=5$ to $9 \%, 3=10$ to $19 \% ; 4=$ 20 to $30 \% ; 5=30$ to $50 \%$; and $6=>50 \%$. Apples were rated before and after treatment. Rater 1 evaluated replications 1 and 3; rater 2 evaluated replications 2 and 4.

Dip treatments of 5 to $7 \mathrm{~min}$ in a 568 liter polypropylene tank were used to remove SB and FS signs. Buffered sodium hypochlorite solutions (Decco Agclor 310 [Elf Atochem Corp., Monrovia, CA] plus an equal volume of Decco 312 Buffer [Elf Atochem] to achieve a $\mathrm{pH}$ of 6.5 ) with chlorine concentrations of 200, 400, 600, or $800 \mathrm{ppm}$ were prepared by incrementally adding the necessary amount of sodium hypochlorite and buffer to the dump tank beginning with nonchlorinated well water and increasing chlorine and buffer concentrations by $200 \mathrm{ppm}$ (0.852 liter sodium hypochlorite and buffer) after each treatment until the $800 \mathrm{ppm}$ concentration was achieved. After the tank was drained and rinsed, 3.8 liters of Kleen 441 (Elf Atochem) was added to 568 liters of nonchlorinated well water (label rate). For each disinfestant and concentration combination, including water-dip controls, 50 'Golden Delicious' and 50 'McIntosh' apples per replication were dipped for 5 to 7 min while turning them continuously to ensure uniform exposure.

Apples were transferred from the dump tank to the conveyor belt of a commercial grading line using a dip net. No-dip controls were placed directly on the grading line. Apples were passed over a series of dry brushes for $10 \mathrm{~s}$, rinsed with tap water for $10 \mathrm{~s}$ under spray nozzles, then passed over additional brushes and a series of foam pads for $10 \mathrm{~s}$. If necessary, apples were pushed along the grading line with a rubber squeegee to ensure uniform time on the brushes. Immediately following treatments, apples were bagged and stored at $1^{\circ} \mathrm{C}$ for 4 to 5 weeks until posttreatment evaluation.

Replications were conducted on four different days. A total of 2,800 apples were included in the experiment [ 2 cultivars $\times(4$ concentrations of chlorine, soap, water control, and no-dip control) $\times 4$ replications $\times 50$ apples per treatment]. Effects of disinfestant, concentration combination, and rater were evaluated using the differences of mean values of before and after severity ratings for 'Golden Delicious' and colony numbers of SB and FS for 'McIntosh' ( $\mathrm{N}=4)$. Disinfestant/ concentration dips were compared using a $t$ test after an analysis of variance was performed for each cultivar. All statistical analyses were performed using SAS software (version 6.2, SAS Institute, Cary, NC).

Experiment 2. Apples ('Jonathan' and 'Golden Delicious') were harvested from a commercial orchard near Indianola, IA, on 9 and 10 September 1999. Trees had not received fungicide applications since approximately 2 weeks after petal fall. Moderately severe levels of SB and FS were observed on all harvested apples. Apples with light SB and FS signs $(<10$ colonies or $<2 \%$ of the apple surface covered by SB and FS) or otherwise defective fruit were not used in the study. Fruit ranging in severity from 3 to $65 \%$ of the surface affected by $\mathrm{SB}$ and FS were stored in wooden crates at $1^{\circ} \mathrm{C}$ for 1 to 4 weeks until they were evaluated for disease severity.

One person performed all disease assessments since, in experiment 1 , significant $(P<0.05)$ differences between individual raters were observed. Using an indelible marker, apples were numbered at the calyx and a line bisecting the fruit was drawn from the stem end to the calyx. Disease severity data were recorded for each side of the apple before and after treatment. Before and after ratings were paired for the same apple by noting its individual number. Two methods of disease assessment were compared. The percent diseased area method involved estimating the percentage of diseased area on the front and back halves of each apple (determined by placement of the line drawn on the fruit) with reference to standard area diagrams depicting diseased areas ranging from 3 to $48 \%$. Standard area diagrams were constructed by projecting photographs of 10 'Golden Delicious' and 10 'Jonathan' apples, displaying a wide range of disease severity, onto acetate sheets. After tracing the outline of each apple, a marker was used to blacken the areas displaying SB or FS signs. The blackened areas on each acetate sheet were quantified using a Delta T Leaf Area Meter (Decagon Devices, Inc., Pullman, WA). Next, the outline of each apple on the acetate sheet was copied onto white paper and cut out. The area of the apple was determined using the same instrument. Percent diseased area was determined as the total diseased area (sum of blackened areas on the acetate sheet) divided by the total area of the paper cutout. Paper images of diseased apples, representing a wide range of disease severity, were pasted onto a poster board and each diagram was labeled with its respective percent diseased area. These standard area diagrams were then used as a reference to estimate percent diseased area of each apple assessed.

The second method of disease assessment involved counting the number of colonies of three distinct mycelial types: flyspeck (FS), having dark fruiting structures (thyrothecia) in discrete groups with no visible mycelial mat; fuliginous (FG), having distinct mycelial mats with no fruiting structures; and punctate/ramose (PR), having dark pycnothyria-like fruiting structures and visible mycelial mats (29). Mycelial types of SB and FS on apples were identified under a circular fluorescent light at $\times 5$ magnification (Model 8MC-100, Dazor, St. Louis, MO). After disease assessment, 10 apples per treatment were arbitrarily selected, placed in perforated plastic bags, and refrigerated at $1{ }^{\circ} \mathrm{C}$ for 1 to 7 days to preserve freshness until apples were subjected to the SB and FS removal process.

Solutions were prepared in 31-liter plastic tubs. Buffered sodium hypochlorite solutions were made from Decco Agclor 310 and an equal volume of Decco 312 Buffer to achieve chlorine concentrations of 200, 500, or 800 ppm. Tsunami 100 (a solution of $11 \%$ hydrogen peroxide and $15 \%$ peroxyacetic acid [Ecolabs, St. Paul, $\mathrm{MN}]$ ) was prepared at concentration ratios of 60:80, 120:160, and 360:480 ppm hydrogen peroxide:peroxyacetic acid (HPPA), respectively. Solutions were prepared 30 min prior to use, and tubs were covered when not in use. Apples were placed in tubs for 7 or $15 \mathrm{~min}$ and turned continuously to ensure uniform exposure. Water controls were placed in nonchlorinated well water in the same manner as disinfestant treatments. Apples were mechanically brushed and rinsed as described for experiment 1 . No-dip controls were placed directly on the grading line.

One replication was conducted each day for eight separate days. There were 2,400 apples included in the experiment $[2$ cultivars $\times(\{[(2$ disinfestants $\times 3$ concentrations) + water control] $\times 2$ dip times $\}+$ nodip control) $\times 8$ replications $\times 10$ apples per replication]. After effects of cultivar, dip time, and disinfestant were evaluated using percent reduction of before and after ratings for each apple, the mean percent reduction data for each 10-apple experimental unit were transformed by the natural $\log$ prior to analysis. All effects were tested using variability between experimental units. A two-factor ANOVA using cultivar and treatment was performed with complete factorial treatment arrangement. The 15 treatments in this analysis represent unique combinations of disinfestant, concentration, and dip time. The cultivar $\times$ disinfestant $\times$ concentration interaction was evaluated; if significant, disinfestant $x$ concentration combination effects were evaluated separately for each cultivar using a one-way ANOVA. The effects of disinfestant, concentration, and dip time on reduction of colony number and percent diseased area were compared using Tukey's studentized range test. Statistical analyses were performed using SAS soft- 
ware, except for the disease assessment methods, which were compared using SigmaPlot 2000 (SPW6, SPSS Inc., Chicago, IL).

Differences between mycelial types and interactions of mycelial type with disinfestant/concentration were compared using a split-plot analysis of variance in which were the main plot effects and mycelial type was the subplot effect. If these interactions were significant, the differences between mycelial types were calculated separately for each combination of cultivar, disinfestant, and concentration. Interacdisinfestant, concentration, and cultivar

tions of cultivar $\times$ mycelial type and cultivar $x$ compound $\times$ mycelial type were tested.

To test the hypothesis that the assessment methods (estimates of percent diseased area and counts of the number of SB and FS colonies) were in good agreement, assessment methods were compared by (i) regressing mean percent diseased area $(y)$ against colony number $(x)$ in posttreatment observations, and (ii) regressing reduction in percent diseased area $(y)$ against reduction in colony number $(x)$. Counting colony number was believed to be less subjective than estimating percent diseased area, so

Table 1. Differences in sooty blotch (SB) and flyspeck (FS) disease severity on apples and percent disease reduction resulting from postharvest 7-min dips in sodium hypochlorite $(\mathrm{Cl})$, soap, water, or a no-dip control followed by $30 \mathrm{~s}$ of scrubbing on a commercial grading line in experiment 1

\begin{tabular}{|c|c|c|c|c|c|}
\hline \multirow[b]{2}{*}{$\begin{array}{l}\text { Pathogen } \\
\text { type }\end{array}$} & \multirow[b]{2}{*}{ Treatment } & \multicolumn{2}{|c|}{$\begin{array}{c}P \text { value of difference } \\
\text { pre- vs. post-treatment }{ }^{w}\end{array}$} & \multicolumn{2}{|c|}{$\%$ Reduction in disease } \\
\hline & & McIntosh & $\begin{array}{l}\text { Golden } \\
\text { Delicious }\end{array}$ & $\operatorname{McIntosh}^{\mathrm{x}}$ & $\begin{array}{l}\text { Golden } \\
\text { Delicious }^{\mathrm{y}}\end{array}$ \\
\hline \multirow[t]{7}{*}{ SB } & No dip & 0.014 & 0.014 & $63 \mathrm{ab}^{\mathrm{z}}$ & $27 \mathrm{~b}$ \\
\hline & Soap & 0.004 & 0.086 & $90 \mathrm{a}$ & $62 \mathrm{a}$ \\
\hline & Water & 0.051 & 0.009 & $59 \mathrm{~b}$ & $27 \mathrm{~b}$ \\
\hline & $200 \mathrm{ppm} \mathrm{Cl}$ & 0.003 & 0.006 & $73 \mathrm{ab}$ & $36 \mathrm{ab}$ \\
\hline & $400 \mathrm{ppm} \mathrm{Cl}$ & 0.011 & 0.006 & $81 \mathrm{ab}$ & $39 \mathrm{ab}$ \\
\hline & $600 \mathrm{ppm} \mathrm{Cl}$ & 0.029 & 0.005 & $82 \mathrm{ab}$ & $51 \mathrm{a}$ \\
\hline & 800 ppm Cl & 0.024 & 0.013 & $86 \mathrm{ab}$ & $54 \mathrm{a}$ \\
\hline \multirow[t]{7}{*}{ FS } & No dip & 0.167 & 0.112 & $80 \mathrm{a}$ & $33 \mathrm{c}$ \\
\hline & Soap & 0.101 & 0.003 & $87 \mathrm{a}$ & $46 \mathrm{bc}$ \\
\hline & Water & 0.042 & 0.007 & $86 \mathrm{a}$ & $51 \mathrm{~b}$ \\
\hline & $200 \mathrm{ppm} \mathrm{Cl}$ & 0.121 & 0.015 & $82 \mathrm{a}$ & $50 \mathrm{~b}$ \\
\hline & $400 \mathrm{ppm} \mathrm{Cl}$ & 0.082 & 0.028 & $89 a$ & $48 \mathrm{~b}$ \\
\hline & $600 \mathrm{ppm} \mathrm{Cl}$ & 0.081 & 0.050 & $85 \mathrm{a}$ & $53 \mathrm{ab}$ \\
\hline & $800 \mathrm{ppm} \mathrm{Cl}$ & 0.086 & 0.003 & $78 \mathrm{a}$ & $65 \mathrm{a}$ \\
\hline
\end{tabular}

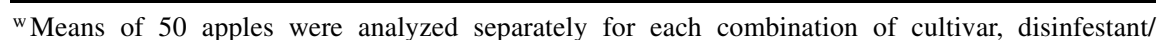
concentration, and pathogen type $(\mathrm{N}=4)$.

${ }^{\mathrm{x}}$ Percent reduction based on number of colonies of SB and FS before and after treatment.

${ }^{y}$ Percent reduction based on a disease severity of SB and FS on a 0 to 6 scale observed before and after treatment.

${ }^{\mathrm{z}}$ Numbers within each column followed by the same letter are not significantly different $(P>0.05)$.

Comparisons were made within cultivar and pathogen type. colony count data were used as the independent variable in regression equations $(19,20)$. Agreement between the percent diseased area estimates and colony number was evaluated for both apple cultivars using the slopes and $y$ intercepts of the regression lines relating percent reduction in colony counts $(x)$ and percent reduction in percent diseased area $(y)(19,20,22)$. Precision was evaluated using the coefficient of determination $\left(R^{2}\right)$, which indicates how much variation in one method (percent diseased area) is explained by another method (colony number), and the standard error of the estimate (SEEy), which is a measure of variation about a predicted $y(21)$.

The economic impact of postharvest removal using disinfestants was estimated after converting the percent diseased area data to USDA grade scores. USDA grade standards (28), based on the percentage of apple fruit surface covered by FS and SB signs, were as follows: Extra Fancy, $<5 \%$; Fancy, 5 to $10 \%$; Utility, 11 to $33 \%$; and Non-graded, $>33 \%$.

Retail values (dollars per bushel) of fresh-market apples (Extra Fancy and Fancy, collectively marketed locally as No. 1) and cider apples (Utility and lower grades) were obtained from four commercial growers in Iowa who marketed their products directly to the public at farmers' markets or roadside stands. We assumed that one bushel contained 160 medium size apples and weighed $18.16 \mathrm{~kg}$. We then compared the estimated retail value of the apples used for each disinfestant and concentration combination before and after the 7-min dip. Retail value estimates were determined in two ways. For sorted apples, dollar values were determined by the proportion of fresh-market and cider apples in

Table 2. Reduction in sooty blotch and flyspeck on 'Golden Delicious' and 'Jonathan' apples as a result of postharvest dips in sodium hypochlorite (Cl), a combination of hydrogen peroxide and peroxyacetic acid (HPPA), water, or no-dip control followed by $30 \mathrm{~s}$ scrubbing on a commercial grading line in experiment 2

\begin{tabular}{|c|c|c|c|c|c|c|}
\hline \multirow[b]{3}{*}{ Treatment } & \multirow[b]{3}{*}{ Concentration (ppm) } & \multirow[b]{3}{*}{ Dip time (min) } & \multicolumn{4}{|c|}{$\%$ Reduction in disease $^{\mathrm{y}}$} \\
\hline & & & \multicolumn{2}{|c|}{ Golden Delicious } & \multicolumn{2}{|c|}{ Jonathan } \\
\hline & & & No. of colonies & $\%$ Diseased area & No. of colonies & $\%$ Diseased area \\
\hline No dip & & & $29 \mathrm{a}^{\mathrm{z}}$ & $19 \mathrm{a}$ & $47 \mathrm{a}$ & $31 \mathrm{a}$ \\
\hline Water & & $\begin{array}{r}7 \\
15\end{array}$ & $\begin{array}{l}36 \mathrm{a} \\
42 \mathrm{ab}\end{array}$ & $\begin{array}{l}23 \mathrm{a} \\
26 \mathrm{ab}\end{array}$ & $\begin{array}{l}64 a b c \\
59 a b c\end{array}$ & $\begin{array}{l}52 \mathrm{ab} \\
49 \mathrm{ab}\end{array}$ \\
\hline HPPA & $\begin{array}{c}80 / 60 \\
80 / 60 \\
160 / 120 \\
160 / 120 \\
480 / 360 \\
480 / 360\end{array}$ & $\begin{array}{r}7 \\
15 \\
7 \\
15 \\
7 \\
15\end{array}$ & $\begin{array}{l}40 a \\
46 a b c \\
47 a b c \\
47 a b c \\
43 a b \\
53 a b c\end{array}$ & $\begin{array}{l}35 \mathrm{ab} \\
33 \mathrm{ab} \\
40 \mathrm{ab} \\
37 \mathrm{ab} \\
33 \mathrm{ab} \\
46 \mathrm{~b}\end{array}$ & $\begin{array}{l}56 \mathrm{abc} \\
57 \mathrm{abc} \\
71 \mathrm{abcd} \\
69 \mathrm{abcd} \\
72 \mathrm{abcd} \\
78 \mathrm{bcd}\end{array}$ & $\begin{array}{l}56 \text { abc } \\
57 \text { abc } \\
62 \text { abcd } \\
60 \text { abcd } \\
65 \text { bcd } \\
70 \text { bcd }\end{array}$ \\
\hline $\mathrm{Cl}$ & $\begin{array}{l}200 \\
200 \\
500 \\
500 \\
800 \\
800\end{array}$ & $\begin{array}{r}7 \\
15 \\
7 \\
15 \\
7 \\
15\end{array}$ & $\begin{array}{l}63 \mathrm{bc} \\
66 \mathrm{~cd} \\
78 \mathrm{de} \\
83 \mathrm{e} \\
86 \mathrm{ef} \\
91 \mathrm{f}\end{array}$ & $\begin{array}{l}56 \mathrm{~cd} \\
62 \mathrm{de} \\
72 \mathrm{ef} \\
76 \mathrm{fg} \\
80 \mathrm{gh} \\
85 \mathrm{~h}\end{array}$ & $\begin{array}{l}81 \mathrm{~cd} \\
77 \mathrm{bcde} \\
84 \mathrm{de} \\
91 \mathrm{ef} \\
92 \mathrm{f} \\
94 \mathrm{f}\end{array}$ & $\begin{array}{l}75 \mathrm{bc} \\
72 \mathrm{bcd} \\
77 \mathrm{de} \\
88 \mathrm{f} \\
87 \mathrm{ef} \\
89 \mathrm{f}\end{array}$ \\
\hline
\end{tabular}

y Values based on (i) percent reduction of number of colonies of sooty blotch and flyspeck, and (ii) percent apple surface area with sooty blotch and flyspeck observed before and after treatment.

${ }^{\mathrm{z}}$ Numbers followed by the same letter within each column are not significantly different at $P>0.05$ according to Tukey's studentized range for log reduction. $\mathrm{N}=80$. 
the population. For unsorted apples, the presence of any cider-quality apples resulted in the entire population being considered cider quality.

\section{RESULTS}

Experiment 1. A high degree of variability was observed in disease severity ratings and colony counts within and between runs of the experiment, especially for pretreatment values. Pretreatment and posttreatment colony counts for 'McIntosh' ranged from 0 to 34 colonies and 0 to 4 colonies, respectively. Disease severity ratings for 'Golden Delicious' ranged from 0 to 6 before treatment and 0 to 4 after treatment. Soap was most effective for the removal of SB signs for 'McIntosh' and 'Golden Delicious' apples, on which percent reductions were 90 and $62 \%$, respectively (Table 1). No-dip and water controls were as effective as chlorine for removing
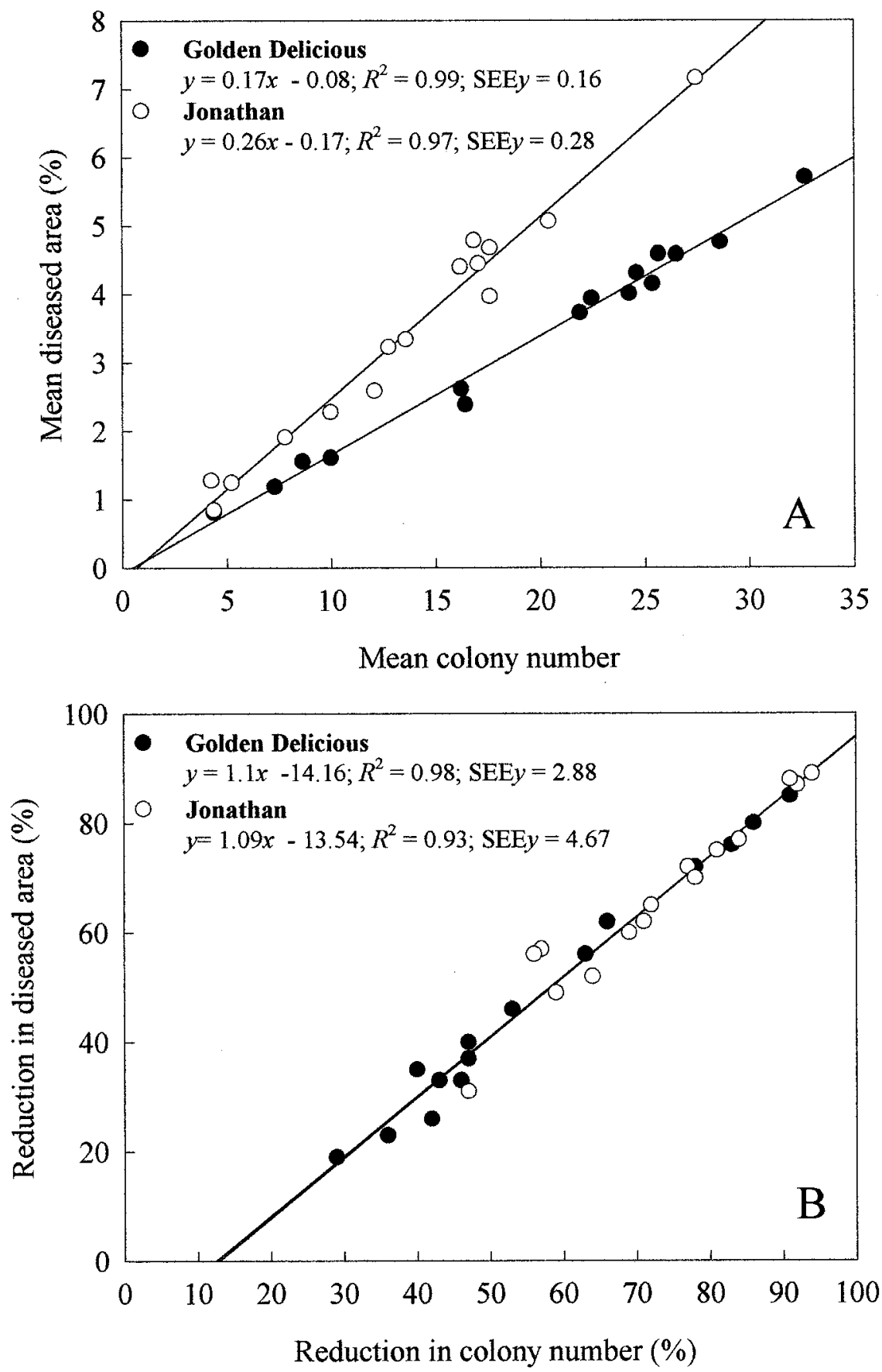

Fig. 1. Regression analysis of A, mean colony number of sooty blotch (SB) and flyspeck (FS) (x) vs. mean percent diseased area of SB and FS (y) on apples after treatment, and $\mathbf{B}$, mean reduction in colony number $(x)$ vs. mean reduction in percent diseased area of SB and FS $(y)$ after dipping 'Golden Delicious' and 'Jonathan' apples for 7 or $15 \mathrm{~min}$ in buffered sodium hypochlorite, a combination of hydrogen peroxide and peroxyacetic acid, or water, followed by $30 \mathrm{~s}$ brushing on a commercial grading line. Treatments were combined $(\mathrm{N}=1,200)$.

SB from 'McIntosh'. Pretreatment ratings of FS on 'McIntosh' were not significantly different from posttreatment ratings, except for the water control (Table 1), but mean percent reduction of FS colonies ranged from 78 to $89 \%$ (Table 1). Chlorine at 800 ppm was the most effective treatment for removing FS from 'Golden Delicious'.

Experiment 2. Both methods of disease assessment (reduction in percent diseased area and reduction in colony number) provided similar results. Overall differences between disinfestant and concentration combinations were significant $(P<$ 0.0001). Reduction of SB and FS severity was significantly $(P<0.0001)$ greater on 'Jonathan' than 'Golden Delicious' apples (data not shown). There were significant ( $P$ $=0.039)$ differences between dip times when cultivar-disinfestant/concentration combinations were analyzed together. Overall, increasing the soak time from 7 to 15 min resulted in the removal of an additional $11 \%$ of SB and FS (data not shown). However, extending the dip time to $15 \mathrm{~min}$ did not significantly increase percent reduction of SB and FS for any dip except for 'Jonathan' in $500 \mathrm{ppm}$ chlorine (Table 2).

The 500 and 800 ppm concentrations of chlorine were more effective than $200 \mathrm{ppm}$ chlorine and all HPPA concentrations in reducing $\mathrm{SB}$ and $\mathrm{FS}$, except for $7 \mathrm{~min}$ of chlorine at $500 \mathrm{ppm}$ (Table 2). In most cases, reduction of diseased area and number of colonies by HPPA, water dips, and the "no dip" control was not significantly different, except for 'Jonathan' at the highest concentration of HPPA (Table 2). There was a significant interaction of cultivardisinfestant/concentration $(P=0.0002)$; for example, $25 \%$ more colonies were removed on 'Jonathan' than on 'Golden Delicious' in the 15-min dip at the highest rate of HPPA (Table 2).

Agreement between disease assessment methods. Individual colonies were, on average, $53 \%$ larger on 'Jonathan' than 'Golden Delicious' (Fig. 1A). When both assessment methods were standardized by converting the data to percent reduction (Fig. 1B), slopes of the regression lines for both cultivars were not significantly different than 1.0, indicating good agreement between the assessment methods (20). There was a significant $(P<0.001)$ linear relationship between reduction of colony number $(x)$ and reduction of percent diseased area $(y)$ for both 'Golden Delicious' and 'Jonathan' apples after treatment (Fig. 1B). The $y$ intercepts for 'Golden Delicious' and 'Jonathan' were significantly $(P$ $=0.0000387$ and $P=0.035$, respectively) less than zero. Estimates of reduction in percent diseased area for 'Golden Delicious' and 'Jonathan' were 14.2 and $13.5 \%$ higher, respectively, than reduction in colony number (Fig. 1B).

Colony number explained 98.8 and $97.4 \%$ of the variation in percent diseased 
area on 'Golden Delicious' and 'Jonathan' apples, respectively (Fig. 1A). Moreover, colony number predicted percent diseased area (SEEy) in 'Golden Delicious' and 'Jonathan' within 0.2 and $0.3 \%$, respectively (Fig. 1A), and percent reduction in colony number explained 98.3 and $93.3 \%$ of the variation in percent reduction in diseased area (Fig. 1B). Percent reduction in colony number predicted estimates of percent diseased area (SEEy) within 2.9 and $4.7 \%$ for 'Golden Delicious' and 'Jonathan', respectively (Fig. 1B).

Effect of mycelial type on removal of SB and FS. Removal of FS, and the SB mycelial types PR and FG, was differentially affected by disinfestant and concentration combination $(P<0.0001)$ (Fig. 2) and cultivar $(P<0.0001)$. There was also an interaction of mycelial type and cultivar for FS and FG $(P=0.0006$ and $P=0.0002$, respectively). On 'Golden Delicious', for example, HPPA, water, and no-dip removed FS and PR more effectively than FG $(P<0.05)$. At high concentrations of chlorine, however, significant differences between PR and FG were not observed on 'Golden Delicious' apples, and less FS than PR or FG was removed with chlorine. On 'Jonathan' apples, significantly $(P<$ $0.0007)$ less FS was removed than PR and FG at all rates of chlorine. The highest rate of HPPA removed significantly $(P<0.006)$ more PR and FG than FS from 'Jonathan' apples. The water dip removed significantly more PR than FS or FG $(P<0.0033$ and $P<0.0153$, respectively).

Effect of postharvest removal of SB and FS on USDA grade and market value. The 7-min 800 -ppm chlorine dip resulted in 100\% Extra Fancy apples for both cultivars (Fig. 3). HPPA dips resulted in 68 to $86 \%$ Extra Fancy, water dips resulted in 60 and $72 \%$ Extra Fancy, and the no-dip control resulted in 47 and $56 \%$ Extra Fancy on 'Jonathan' and 'Golden Delicious', respectively.

Retail prices obtained in March 2001 from four commercial apple growers in Iowa indicated large differences between fresh-market and cider apple prices. Cider apples sold for $\$ 2.00$ per bushel at all orchards, while the mean price of freshmarket apples was \$32 per bushel when sold at roadside stands and farmers' markets. Retail values ranged from $\$ 22$ to $\$ 48$ per bushel depending upon the local market, cultivar, and fruit size. The growers interviewed in this study did not market apples as processing fruit.

The greatest increase in retail value was obtained with chlorine dips (Table 3 ). If a vendor sorted the apples manually into fresh-market and cider grades, the 7-min dip in $800 \mathrm{ppm}$ chlorine increased the value of 'Golden Delicious' and 'Jonathan' apples by $\$ 4.50$ and $\$ 9.76$ per bushel, respectively. The HPPA dips also increased retail value substantially, since Fancy and Extra Fancy apples were considered to have the same retail value. If apples were left unsorted and mixed grades were marketed as cider apples at $\$ 2.00$ per bushel, then the 7-min dip in 800 ppm chlorine for 'Jonathan' and 'Golden Delicious' apples and the 200 and 500 ppm chlorine dips for 'Golden Delicious' increased retail value by $\$ 30.00$ per bushel. The other disin- festant/concentration dips substantially increased the retail value of the apples but did not eliminate the need to sort the apples in order to gain economic benefits.

\section{DISCUSSION}

The results of both experiments indicated that chlorine reduced FS and SB
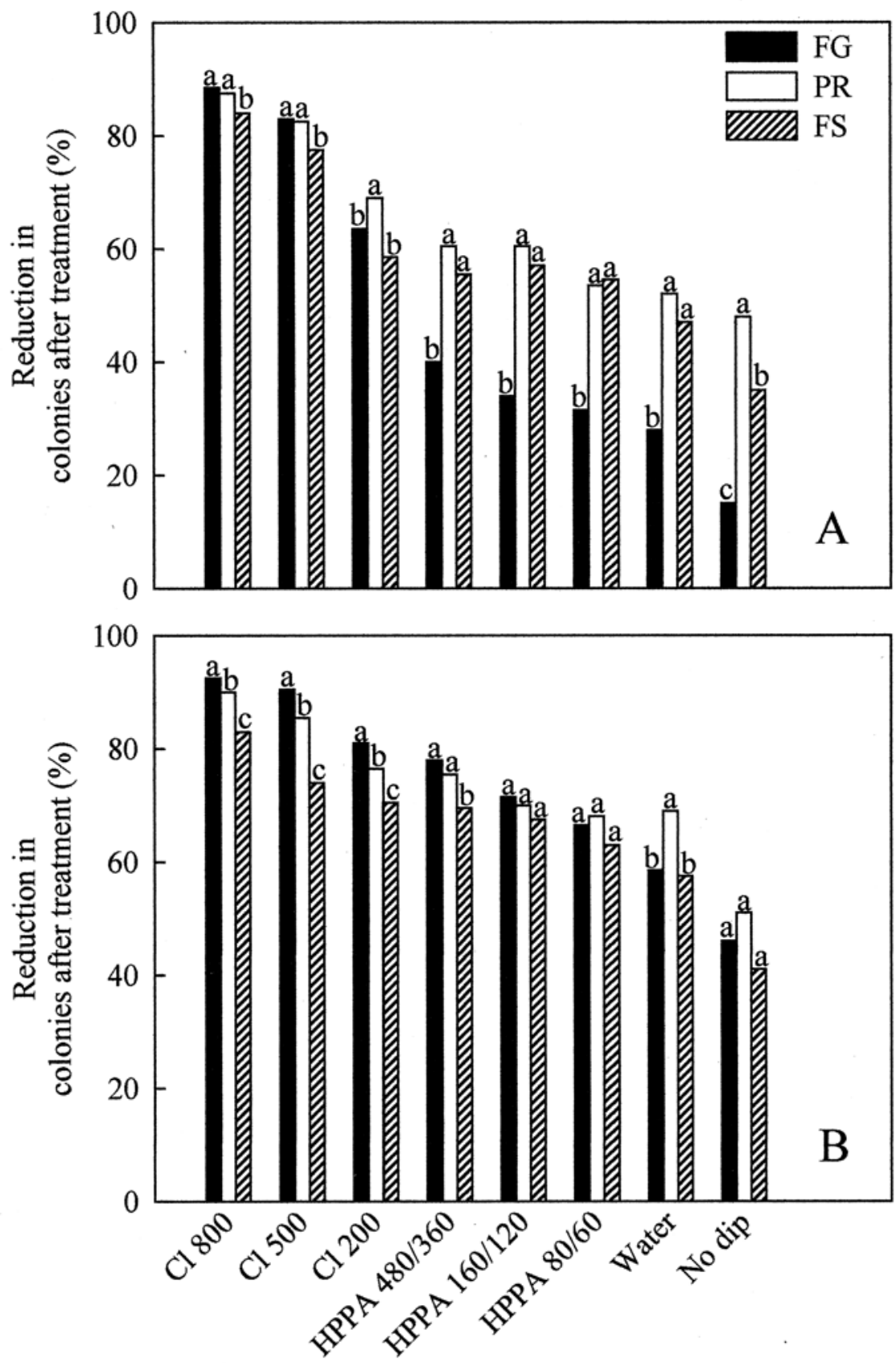

Fig. 2. Percent reduction in number of three mycelial types of the flyspeck (FS) and sooty blotch (SB) complex on A, 'Golden Delicious' and B, 'Jonathan' apples after a dip in two disinfestants, water or "no-dip" followed by $30 \mathrm{~s}$ brushing on a commercial grading line. Disinfestant treatments included three concentrations of buffered sodium hypochlorite $(800,500$, or $200 \mathrm{ppm} \mathrm{Cl})$, three concentrations of a combination of hydrogen peroxide and peroxyacetic acid (HPPA) (480 ppm hydrogen peroxide [HP] and $360 \mathrm{ppm}$ peroxyacetic acid [PA], $160 \mathrm{ppm} \mathrm{HP}$ and $120 \mathrm{ppm}$ PA, or 80 ppm HP and 60 ppm PA). Each compound was analyzed separately, and bars with the same letter within each compound grouping are not significantly different at $P>0.05$ according to Student's $t$ test. Mycelial types were distinguished as: FS (flyspeck), having fruiting structures (thyrothecia) with no visible mycelial mat; FG (fuliginous), having distinct mycelial mats and without fruiting structures; and PR (punctate/ramose), having pycnothyria-like fruiting structures and dark mycelial mats. Dip times (7 and $15 \mathrm{~min}$ ) were combined. $\mathrm{N}=160$. 

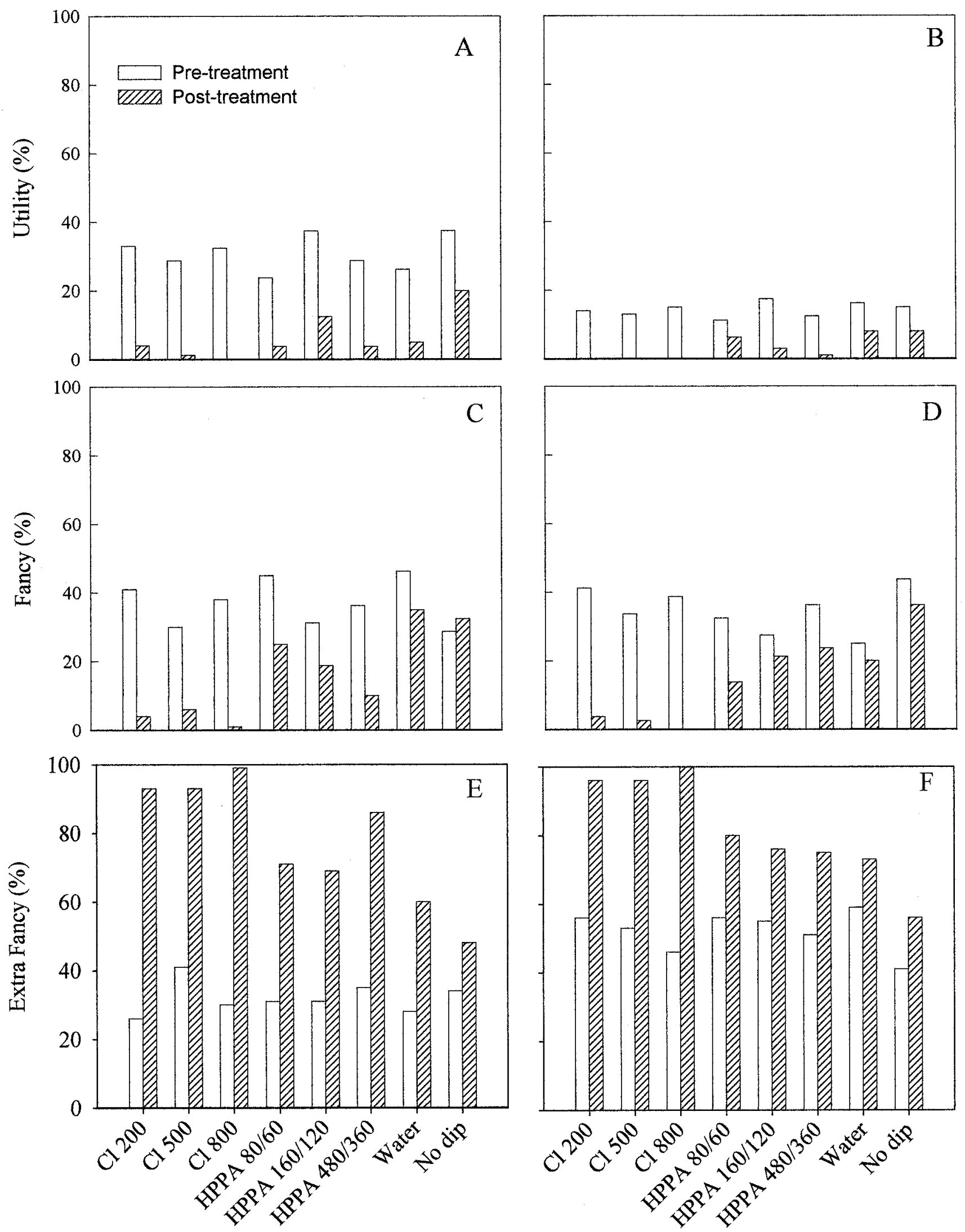

Fig. 3. USDA grade of 'Jonathan' (A, C, E) and 'Golden Delicious' (B, D, F) apples before and after a 7-min dip in 200, 500, or 800 ppm buffered sodium hypochlorite or a mixture of hydrogen peroxide/peroxyacetic acid (HPPA) at 80 ppm hydrogen peroxide (HP) and 60 ppm peroxyacetic acid (PA), 160 ppm HP and $120 \mathrm{ppm} \mathrm{PA}$, or $480 \mathrm{ppm}$ HP and $360 \mathrm{ppm}$ PA, then brushed and rinsed for $30 \mathrm{~s}$ on a commercial grading line. N $=80$. USDA grade standards were defined as follows: Extra Fancy fruit have $<5 \%$ of the surface covered by sooty blotch (SB) and flyspeck (FS); Fancy fruit have 5 to $10 \%$ of the surface covered by SB and FS; Utility fruit have 11 to $33 \%$ of the surface covered by SB and FS. 
signs on 'Golden Delicious' apples by 50 to $85 \%$. While the design of experiment 1 prevented close examination of the effects of disinfestant/concentration, cultivar, and mycelial type on the removal process, mean percent reduction of SB and FS was similar to results of experiment 2. Experiment 2 was designed to reduce the data variability obtained in experiment 1 by using a single rater, developing a standard area diagram, labeling the apples individually, pairing before- and after-treatment ratings for the same apple, and increasing the number of runs from four to eight.

Results from experiment 2 showed that a 7-min dip in 800 ppm chlorine, followed by $30 \mathrm{~s}$ of brushing and rinsing, reduced SB and FS sufficiently to yield $100 \%$ Extra Fancy grade apples, regardless of initial disease level. The 200-ppm (label rate) and 500-ppm chlorine treatments were also highly effective, resulting in 92.5 and 96.5\% Extra Fancy posttreatment 'Jonathan' and 'Golden Delicious' fruit, respectively. However, these lower chlorine concentrations resulted in a small percentage of 'Jonathan' apples (4\%) that remained in the Utility grade. Water and HPPA treatments were not effective for the removal of $\mathrm{SB}$ and FS, as evidenced by the relatively large number of Utility apples after treatment. Increasing dip time to $15 \mathrm{~min}$ increased the effectiveness of removal of SB and FS by $11 \%$, but one or two Utility grade apples per batch were present even after $15 \mathrm{~min}$ in $200 \mathrm{ppm}$ chlorine. Our study indicates that increasing the dip time from 7 to $15 \mathrm{~min}$ would not be a costeffective strategy to increase USDA grade scores of apples. Furthermore, increasing the dip time to $15 \mathrm{~min}$ may be impractical because it would slow the rate of apple processing unacceptably.

Disease assessment methods in our study differed from those of Hendrix (10). We evaluated disease severity, whereas Hendrix evaluated disease incidence, which obscures differences among levels of disease severity. Hendrix reported that a 5- to 7-min dip in $500 \mathrm{ppm}$ chlorine removed all SB and $73 \%$ of FS from apples, whereas we obtained a reduction of $81 \%$ of SB and $75 \%$ of FS colonies for 'Golden Delicious' and a reduction of $85 \%$ of SB and $70 \%$ of FS colonies for 'Jonathan' apples after a 7-min dip in 500 ppm chlorine. A possible explanation for these differences is that the fungal species and mycelial types in Georgia may differ from those present in our Iowa study. The amount of brushing the apples received after treatment also may have differed between the two studies. Hendrix (10) reported that apple cultivar ('Red Delicious', 'Golden Delicious', 'Granny Smith', 'Rome Beauty', 'Gala', 'Jonathan', 'Stayman', and 'Empire') did not affect removal of SB and FS, whereas our results clearly indicated that more SB and FS were removed from 'Jonathan' and 'McIntosh' than 'Golden Delicious'. The chemical composition of epicuticular wax varies among apple cultivars (2), and characteristics of the wax may have influenced the removal of SB and FS by disinfestant compounds and the action of the brushes.

Converting percent diseased area assessment data to USDA grade values provided a means to evaluate treatment effects in economic terms, although the benefits to sale value by postharvest dip treatments will vary according to season and location. In Iowa, locally grown apples are marketed as No.1, which includes Extra Fancy and Fancy grades. The USDA shipping point values are based on Extra Fancy, Peelers, and Cider grades. Manually sorting out these Utility grade apples would substantially add to the cost of treatment (8). The cost of sorting the apples must be considered when determining the feasibility of postharvest treatment, and may be more affordable for high-value cultivars or in markets with less exacting cosmetic standards.

Table 3. Estimated increase in retail value of apples resulting from removal of sooty blotch (SB) and flyspeck (FS) signs by a 7-min postharvest dip in sodium hypochlorite $(\mathrm{Cl})$, a combination of hydrogen peroxide and peroxyacetic acid (HPPA), water, or no-dip control followed by $30 \mathrm{~s}$ of scrubbing and a water rinse on a commercial grading line

\begin{tabular}{|c|c|c|c|c|c|}
\hline \multirow[b]{3}{*}{ Compound } & \multirow{3}{*}{$\begin{array}{c}\text { Concentration } \\
(\mathbf{p p m})\end{array}$} & \multicolumn{4}{|c|}{ Increased retail value $\left(\$ / \mathbf{k g}^{\mathrm{x}}\right)$} \\
\hline & & \multicolumn{2}{|c|}{ Golden Delicious } & \multicolumn{2}{|c|}{ Jonathan } \\
\hline & & Sorted $^{\mathrm{y}}$ & Unsorted $^{\mathrm{z}}$ & Sorted $^{y}$ & Unsorted $^{\mathrm{z}}$ \\
\hline $\mathrm{Cl}$ & $\begin{array}{l}200 \\
500 \\
800\end{array}$ & $\begin{array}{l}0.21 \\
0.21 \\
0.25\end{array}$ & $\begin{array}{l}0 \\
1.65 \\
1.65\end{array}$ & $\begin{array}{l}0.47 \\
0.45 \\
0.54\end{array}$ & $\begin{array}{l}0 \\
0 \\
1.65\end{array}$ \\
\hline HPPA & $\begin{array}{c}80 / 60 \\
160 / 120 \\
480 / 360\end{array}$ & $\begin{array}{l}0.07 \\
0.23 \\
0.19\end{array}$ & $\begin{array}{l}0 \\
0 \\
0\end{array}$ & $\begin{array}{l}0.33 \\
0.41 \\
0.41\end{array}$ & $\begin{array}{l}0 \\
0 \\
0\end{array}$ \\
\hline Water & & 0.14 & 0 & 0.35 & 0 \\
\hline No dip & & 0.12 & 0 & 0.29 & 0 \\
\hline
\end{tabular}

${ }^{x}$ Dollar values of apples were based on the proportion of USDA grades that could be marketed as fresh-market or cider apples, assuming $\$ 1.76 / \mathrm{kg}$ and $\$ 0.11 / \mathrm{kg}$ for No. 1 fresh-market and cider apples and $18.16 \mathrm{~kg} / \mathrm{bu}$ for medium-size apples.

${ }^{y}$ Cost of sorting is not included in the analysis.

${ }^{\mathrm{z}}$ All apples were used for cider if any portion of the population was lower than USDA grade Fancy.
The percent diseased area assessment method provided an accurate evaluation of disease severity on three-dimensional surfaces. Counting colonies required an average of $90 \mathrm{~s}$ per apple. In contrast, assessing percent diseased area provided an accurate estimation of disease severity percent and required an average of only $15 \mathrm{~s}$ per apple, regardless of disease severity. Although the reduction in percent diseased area consistently overestimated reduction in colony number by about $14 \%$ for both cultivars, this bias was constant and did not affect our conclusions regarding comparisons of disinfestant compound, concentration, dip time, or cultivar. Raters tend to overestimate disease severity when large numbers of small lesions are present (5). The occasional differences in disinfestant dip effects between the two assessment methods may have resulted from partial removal of colonies during treatment, more frequent removal of small colonies than of large colonies, or the fact that colony number counts ignored colony size. Percent diseased area took into account the size of the colonies and provided a measure of disease severity, whereas colony number provided a measure of the frequency of mycelial types (FS, PR, FG). The diseased area assessment method developed in this study has potential for application to other threedimensional sampling units beyond the apple/SBFS pathosystem.

The present study is the first to document differential removal of FS and SB mycelial types and interactive effects between treatment and cultivar on effectiveness of postharvest treatments. Therefore, mycelial type and cultivar should be considered when evaluating effectiveness of a postharvest treatment on SB and FS removal. Differences in the composition of epicuticular wax of 'Jonathan' and 'Golden Delicious' apples (2) may have been a factor in differential removal of mycelial type, as well as an explanation of the $53 \%$ greater colony size on 'Jonathan' compared to 'Golden Delicious'. Although the effectiveness of disinfestant treatments may vary with cultivar, mycelial type, and environmental conditions during the growing season, postharvest removal of SBFS is an effective tool in increasing the retail value of fresh-market apples.

\section{ACKNOWLEDGMENTS}

We thank Matt and Wendy McGinniss for providing apples used in this study and Jennifer McGuire, Matthew Priebe, Dan Thorpe, Jenny Siegner, Will Emley, Lynn Schroeder, Jack Guan, and Stephen Wegulo for technical assistance. The research was supported by a grant from the Leopold Center for Sustainable Agriculture, Ames, IA.

\section{LITERATURE CITED}

1. Batzer, J. C., Gleason, M. L., and Nutter, F. W., Jr. 2001. Post-harvest removal of sooty blotch and flyspeck on apples using commercial disinfestants. (Abstr.) Phytopathology 91:S7.

2. Belding, R. D., Blankenship, S. M., Young, 
E., and Leidy, R. B. 1998. Composition and variability of epicuticular waxes in apple cultivars. J. Am. Soc. Hortic. Sci. 123:348-356.

3. Beuchat, L. R., Nail, B. V., Adler, B. B., and Clavero, M. R. S. 1998. Efficacy of spray application of chlorinated water in killing pathogenic bacteria on raw apples, tomatoes, and lettuce. J. Food Prot. 61:1305-1311.

4. Brown, E. M., and Sutton, T. B. 1993. Time of infection of Gloeodes pomigena and Schizothyrium pomi on apple in North Carolina and potential control by an eradicant spray program. Plant Dis. 77:451-455.

5. Campbell, C. L., and Madden, L. V. 1990. Introduction to Plant Disease Epidemiology. John Wiley \& Sons, New York.

6. Colby, A. S. 1920. Sooty blotch of pomaceous fruits. Trans III. Acad. Sci. 13:139-179.

7. Cooley, D. R., Gamble, J. W., and Autio, W. R. 1997. Summer pruning as a method for reducing flyspeck disease on apple fruit. Plant Dis. 81:1123-1126.

8. Gold, H. J., and Sutton, T. B. 1989. Past orchard performance as a guide to decisions on use of fungicides to control sooty blotch and flyspeck. Crop Prot. 7:258-266.

9. Groves, A. B. 1933. A study of the sooty blotch disease of apples and causal fungus Gloeodes pomigena, Va. Agric. Exp. Stn. Bull. 50:1-43.

10. Hendrix, F. F., Jr. 1991. Removal of sooty blotch and flyspeck from apple fruit with a chlorine dip. Plant Dis. 75:742-743.

11. Honnay, R. 1988. Process for improving the preservation of fruits and vegetables. European Patent 0255814

12. Johnson, E. M. 1994. Etiology of the apple sooty blotch disease and temperature and rela- tive humidity effects on development of the fungi in the associate complex. Ph.D. diss. North Carolina State University, Raleigh.

13. Johnson, E. M., and Sutton, T. B. 2000. Response of two fungi in the apple sooty blotch complex to temperature and relative humidity. Phytopathology 90:362-367.

14. Johnson, E. M., Sutton, T. B., and Hodges, C. S. 1996. Peltaster fructicola: A new species in the complex of fungi causing apple sooty blotch disease. Mycologia 88:114-120.

15. Johnson, E. M., Sutton, T. B., and Hodges, C. S. 1997. Etiology of apple sooty blotch disease in North Carolina. Phytopathology 87:88-95.

16. Jones, A. L., and Sutton, T. B. 1996. Diseases of Tree Fruits in the East. Mich. State Univ. Ext. Publ. E154.

17. Main, C. E., and Gurtz, S. K. 1988. 1987 Crop Losses due to Plant Disease and Nematodes. N.C. State Univ. Dep. Plant Pathol. Spec. Publ. 8.

18. Nasu, H., and Kunoh, H. 1987. Scanning electron microscopy of flyspeck of apple, pear, Japanese persimmon, plum, Chinese quince, and pawpaw. Plant Dis. 71:361-364.

19. Nutter, F. W., Jr., Gleason, M. L., Jenco, J. H., and Christians, N. C. 1993. Assessing the accuracy, intra-rater repeatability, and inter-rater repeatability of disease assessment systems. Phytopathology 83:806-812.

20. Nutter, F. W., Jr., and Schultz, P. M. 1995. Improving the accuracy and precision of disease assessments: Selection of methods and use of computer-aided training programs. Can. J. Plant Pathol. 17:174-184.

21. Nutter, F. W., Jr., Teng, P. S., and Shokes, F. M. 1991. Disease assessment terms and con- cepts. Plant Dis. 75:1187-1188.

22. O'Brien, R. D., and van Bruggen, A. H. C. 1992. Accuracy, precision, and correlation to yield loss of disease severity scales for corky root of lettuce. Phytopathology 82:91-96.

23. Ocamb-Basu, C. M., and Sutton, T. B. 1988.

The effects of temperature and relative humidity on germination, growth, and sporulation of Zygophiala jamaicensis. Phytopathology 78:100-103.

24. Rosenberger, D. A., Engleberger, F. W., and Meyer, F. W. 1996. Effects of management practices and fungicides on sooty blotch and flyspeck diseases and productivity of Liberty apples. Plant Dis. 80:798-803.

25. Sapers, G. M., and Simons, G. F. 1998. Hydrogen peroxide disinfection of minimally processed fruits and vegetables. Food Tech. 52:48-52.

26. Spotts, R. A., and Peters, B. B. 1980. Chlorine and chlorine dioxide for control of d'Anjou pear decay. Plant Dis. 64:1095-1097.

27. Sutton, A L, and Sutton, T B. 1994. The distribution of the mycelial types of Gloeodes pomigea on apples in North Carolina and their relationship to environmental conditions. Plant Dis. 78:668-673.

28. United States Standards for Grades of Apples. 1995. U.S. Dep. Agric. Bull. 492. On-line publication.

29. Williamson, S. M., and Sutton, T. B. 2000. Sooty blotch and flyspeck of apple: Etiology, biology, and control. Plant Dis. 84:714-724.

30. Winsiewsky, M. A., Glatz, B. A., Gleason, M. L., and Reitmeier, C. A. 2000. Reduction of Escherichia coli $\mathrm{O} 157: \mathrm{H} 7$ counts on whole fresh apples by treatment with sanitizers. J. Food Prot. 63:703-708. 